Volume 3, Issue 1 (Winter 2011)

\title{
Producing the Vernacular: Antwerp, Cultural Archaeology and the Bruegelian Peasant
}

Stephanie Porras

Recommended Citation:

Stephanie Porras, "Producing the Vernacular: Antwerp, Cultural Archaeology and the Bruegelian Peasant," JHNA 3:1 (Winter 2011), DOI: 10.5092/jhna.2011.3.1.3 Available at https://jhna.org/articles/producing-vernacular-antwerp-cultural-archaeology-bruegelian-peasant/

Published by Historians of Netherlandish Art: https://hnanews.org/

Republication Guidelines: https://jhna.org/republication-guidelines/

Notes: This PDF is provided for reference purposes only and may not contain all the functionality or features of the original, online publication. This is a revised PDF that may contain different page numbers from the previous version. Use electronic searching to locate passages. This PDF provides paragraph numbers as well as page numbers for citation purposes.

ISSN: $1949-9833$ 


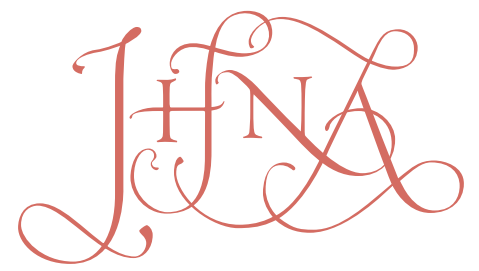

\section{PRODUCING THE VERNACULAR: ANTWERP, CULTURAL AR- CHAEOLOGY AND THE BRUEGELIAN PEASANT}

\section{Stephanie Porras}

From the mid-sixteenth century, Antwerp saw an explosion of printed histories, etymological research into place names, and Netherlandish dialects, as well as the publication of Dutch dictionaries and grammars. Simultaneously, Antwerp's art market saw a boom in the production of peasant scenes and the rising fame of Pieter Bruegel the Elder. In this article, I will argue that in both pictorial and textual representation, the peasant acted as a metaphoric vehicle, a type of living archaeological record and embodiment of local history, central to the production of a uniquely "Netherlandish" vernacular cultural identity. 10.5092/jhna.2011.3.1.3 Ior two days in 1520, extreme low tides exposed a ruined structure in the vicinity of Katwijkop-Zee, a seaside village near Leiden. The Netherlandish historian Cornelius Aurelius was the first to describe what he termed "the tower of Calla," a stone ruin visible at low tide from the shore; he postulated that the tower was the remnant of a Roman frontier fort. ${ }^{1}$ He hypothesized that the fort, positioned at the mouth of the Rhine, had been used by the Roman army as a base for excursions to Britain. The site thus became known as the Arx Britannica, or Brittenberg. By the middle of the sixteenth century, the ruins at Brittenberg were famous enough to merit inclusion in Sebastian Münster's 1550 Cosmographiae universalis (fig. 1). ${ }^{2}$ Subsequent low tides in 1552 and 1562 led to further excavation of the site.

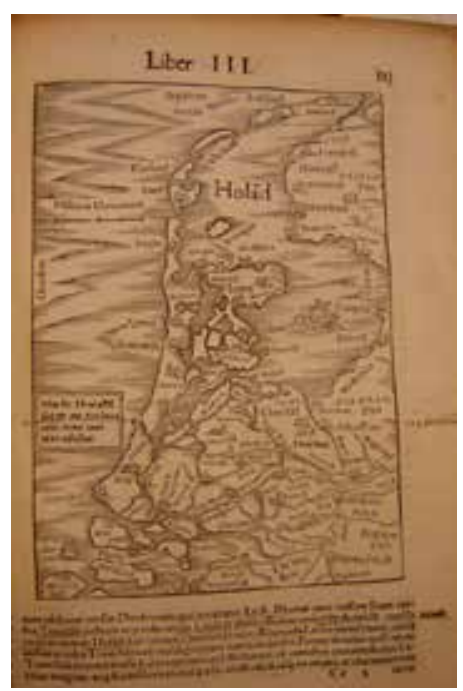

Fig 1. Anonymous German, Map of Holland, from Sebastian Münster, Cosmographiae universalis, 1550, fol. 513, woodcut, $25.3 \times 17.4 \mathrm{~cm}$, London, British Museum 


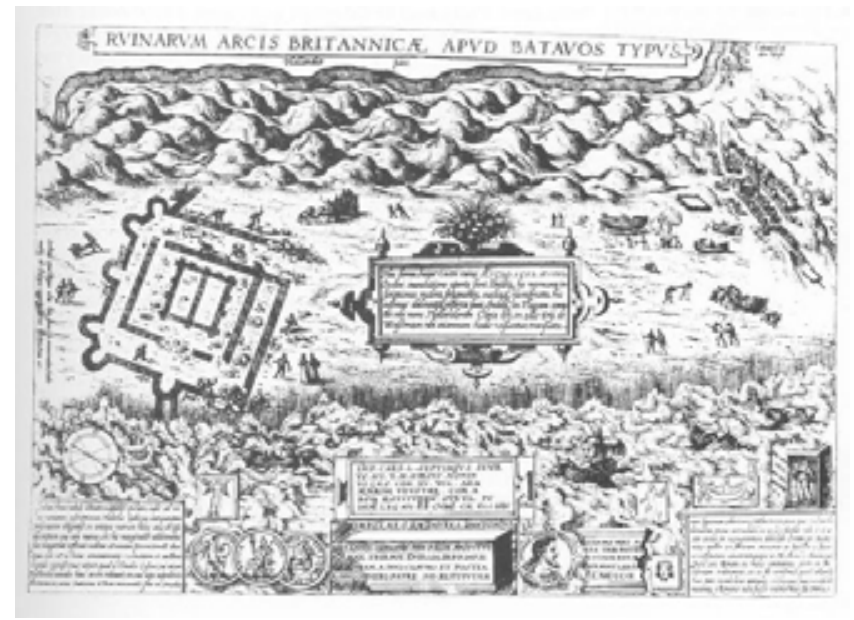

Fig 2. Abraham Ortelius, Arx Britannica, 1566-68, engraving, $32.4 \times 23.2 \mathrm{~cm}$, London, British Library

The Arx Britannica was also the subject of one of Abraham Ortelius's earliest published maps, executed between 1566 and 1568 (fig. 2) and published in Antwerp. ${ }^{3}$ Although the sheet is undated, surviving letters indicate that Ortelius had discussed the Arx Britannica with both the esteemed numismatist and antiquarian Hubertus Goltzius and the philologist Guido Laurinus from 1566; both may have been active collaborators in the map's production. ${ }^{4}$ Ortelius produced the first known plan of the archaeological site, inserted into a topographical view of the landscape. The cartographer also included snippets of text on the Batavians from Tacitus's Germania, images of several items found at Brittenberg: stones bearing inscriptions and carvings, as well as an intact roof tile from the original antique structure. First issued as a separate sheet, the map would also be incorporated in the 1581 edition of Ludovico Guicciardini’s Descrittione di tutti i Paesi Bassi (Description of All the Low Countries). Guicciardini had included a textual description of the ruin in his original 1567 text, describing how local peasants had found stones inscribed "x. G.I." (which he took to mean ex germanae inferioris [of lower Germany]), as well as several medals and other antiquities near the site. ${ }^{5}$

3 The antique ruins of Brittenberg, far to the north of Antwerp, were described and promoted by later-sixteenth-century humanists based in the city on the Schelde as being particularly representative of the Low Countries' unique historical cultural identity. Ortelius's image of the site is a strange jumble of texts, schematic plan, topographical view, and, crucially, also something approaching a genre scene. The laborers at work excavating, or perhaps removing stones from the site, are most likely peasants. These laborers are clearly from a lower order than those figures represented as approaching on foot and in coaches to look at the site - one laborer even doffs his hat as a pair of figures approach the ruin.

During this period, sites of archaeological importance were often first discovered by rural people engaged in plowing fields and other agricultural tasks, who brought inscribed stones, medals, and other items to the attention of scholars and the wider public. While some blamed peasants for stealing or reusing antique stones and objects, others, like the numismatist Guillaume du Choul, relied on agricultural workers bringing him antique coins to study. ${ }^{6}$ In the case of Brittenberg, Guicciardini acknowledged the peasants' role in finding antiquities at the site and in publicizing the ruin, yet he also insinuated that the peasantry was ignorant and pilfered stones from the site. ${ }^{7}$ 
Thus, the peasant unearthed the remnants of antiquity but remained unaware of the importance of his find. Ortelius shows the ruin itself in a schematic perspective, with the result that the peasants dig and move stones around a curiously two-dimensional pictogram hovering in a somewhat flattened perspectival space. While the peasants engage with the ruin at the level of the stones themselves, the viewer confronts the schematic plan of the ruin. It is the buyer of Ortelius's print, the reader of Guicciardini's text, who must make sense of the archaeological discovery, to build a history around the artifacts found and unrecognized by the peasant.

6 I have begun with this unusual map because I believe it represents the complex nexus of ideas at play in the late sixteenth-century Netherlandish concept of a "vernacular" culture as a place where classical antiquity, local history, and the peasant meet. It was in Antwerp, the multicultural, mercantile, intellectual, and publishing center of the Low Countries, where multifaceted and often conflicting concepts of the vernacular were produced. The incipient field of archeology, the growing interest in the collection of language and customs, and the representation of the peasant in both text and image, all had a role in this process.

\section{Defining and Defending the Vernacular}

7 In the most direct sense, the word "vernacular" (from the Latin vernaculus, meaning domestic or native) is taken in English to mean local language and idiom. The second half of the sixteenth century saw the widespread publication of multilingual dictionaries and grammars resulting in an increasingly systematized Dutch vernacular. ${ }^{8}$ The demand for dictionaries was itself the product of the runaway success of the printed media, in particular, the demand for translations of popular works and the need to disseminate information - be it governmental edicts, humanist ideas, religious views, geographical or scientific discoveries - across linguistic boundaries. Reflecting the perceived necessity for vernacular translation, Cornelis van Ghistele, in the preface to his Dutch translation of the Aeneid, lamented: "menich constich gheest daerduere hem ontsiet ende grouwelt yet in onser Dutyscher talen over te settene (many an artful mind is frightened and recoils from translating anything into our Dutch language)."

To assist in the process of translation, Dutch dictionaries, like the Latin-Greek-French-Dutch Dictionarium tetraglotton published by Christopher Plantin in 1562, began to appear with regularity in the later sixteenth century. Yet the systematization of the vernacular was not only aimed at easing the task of the translator. The Antwerp lawyer Jan van der Werve, in his 1553 legal dictionary Het Tresoor der Duytsscher Talen, argued for the increased use of the vernacular by appealing to the historic character of the Dutch language, writing:

Helpt my ons moeders tal (die ghelijck goudt onder deerde
leyt verborghen) wederom so brenghen op de beene, dat sy
aen andere talen geen onderstant en behoeft te versoecken.

(Help me, to raise up our mother language [which now lies concealed in the earth like gold], so that we may prove how needless it is for us to beg for the assistance of other languages). ${ }^{10}$

Van de Werve not only uses the evocative term, "mother tongue," for the vernacular, he also 
compares the Dutch language to an archaeological find or precious natural resource, lying buried beneath the earth.

The use of the vernacular was thus increasingly mobilized as a unique cultural and historical asset. ${ }^{11}$ Van de Werve's appeal was aimed not only at increasing the use of the Dutch language but also at codifying and preserving it. This meant eliminating foreign words from the language. In 1559, Van de Werve would go so far as to republish his dictionary, replacing the French-derived Tresoor in the title for the more suitably Dutch Schat. Dirck Volckertszoon Coornhert also advocated a return to the purity of "onse nederlandsche sprache (our Netherlandish speech)" in the preface to his 1561 translation of Cicero's De Officiis. ${ }^{12}$

10 The search for linguistic purity was often mixed with an antiquarian concern for the preservation of the perceived "historical" state of the language. The historical value of the Dutch language assumed phenomenal stature in the 1560s, reaching a climax in 1569 with Johannes Gropius Becanus's assertion that Diets, the local dialect of Antwerp, was in fact a direct linguistic descendant from the language of Adam. ${ }^{13}$ While Becanus's views remained extreme, historical accounts of European languages appeared with greater regularity in the later sixteenth-century, acknowledging the vernacular's capacity to be transformed through time. ${ }^{14}$ Recognizing the historical value of the Dutch language allowed for the recovery of the past not only through the manipulation of the physical remains of antiquity at archaeological sites such as Brittenberg but also through linguistic research. Etymology, the study of the origins of words and place names, arose as a kind of textual archaeology and was used by Becanus, Ortelius, and Petrus Divaeus to establish the antiquity of Netherlandish towns and cities. ${ }^{15}$

11 The collection of vernacular oral traditions, such as songs and proverbs, was not unrelated to the etymological and linguistic interests of antiquarians and humanists. In the preface to Tylman Susato's collection of songbooks published between 1551 and 1561, the publisher writes that he wants to celebrate "onse...nederlandsche moeder talen (our Netherlandish mother language," as well as "onse vaderlandsche musycke (our fatherland's music)." ${ }^{16}$ In a similar fashion, proverb collections such as Symon Andriessoon's 1550 Adagia ofte Spreecwoorden, published in Antwerp by Heynrick Alssens, encouraged the historical valuation of the vernacular by gathering traditional idioms and publishing them alongside antique proverbs rendered into Dutch. ${ }^{17}$ Words, phrases, idioms, and songs could all be collected and discussed as representative of a distinctly Dutch vernacular, a language with its own historical value and scholarly merit.

12 The peasant, besides playing a direct and active role in contemporary archaeological discoveries like that at Brittenberg, was also an important symbolic figure in the establishment of this Dutch vernacular. The music included in Susato's songbooks often had rural origins, with the author indicating in the titles given to the songs, such as "de Poitou" or "for the Kermis of St. Jans.," the particular village, region, or kermis where the song/dance was performed., Perhaps the most famous example of this localization of songs and dances is Susato's inclusion of a popular song associated with the kermis of Hoboken, represented by Pieter Bruegel the Elder in an engraving of 1559 (fig. 3). ${ }^{18}$ Both Susato and Bruegel transform the ephemeral products of a peasant culture into something to be consumed by an urban, educated audience, giving historical permanence to transient phenomena, as well as providing a validation of local popular culture. Custom, as a 


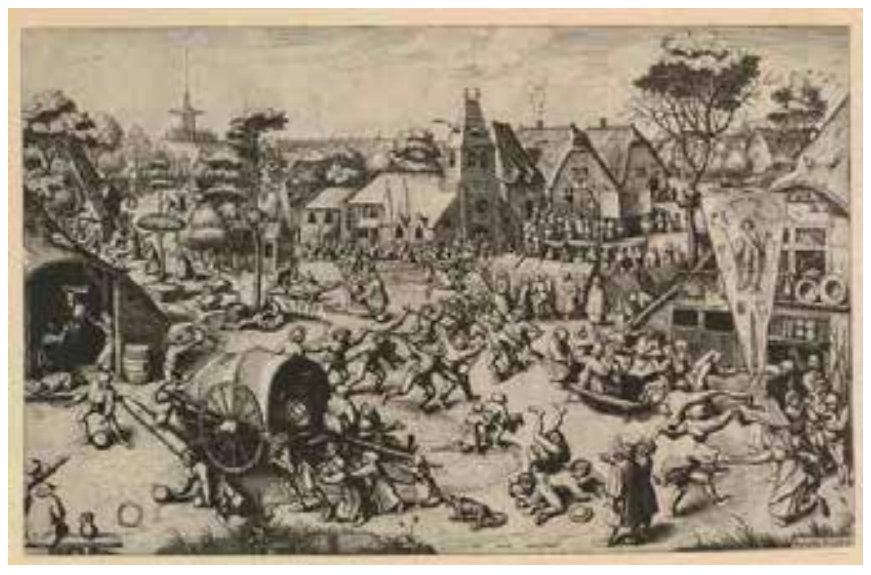

Fig 3. Johannes and Lucas van Doetecum (after Pieter Bruegel), Kermis at Hoboken, 1559, engraving, $32.7 \mathrm{x}$ $51.6 \mathrm{~cm}$, London, British Museum

place where vernacular language, lived experience, and peasant practice meet, is an authoritative source for both artist and publisher. ${ }^{19}$

13 With few physical monuments or antique textual accounts to rival those of Rome, early Dutch historians had to find alternative foundations upon which to build their descriptions of the ancient Netherlandish people. Increasingly, a historical sense of Dutch identity was vested in linguistic and etymological research, as noted above, as well as in the collection of vernacular cultural traditions. Simultaneous with the explosion of printed dictionaries, songbooks, and proverb collections, Antwerp's art market also saw a boom in the production of peasant scenes depicting rural villagers at work and, more often, at play. While the rise of the peasant genre in the visual culture of sixteenth-century Antwerp has been discussed in relation to the rise of an urban, bourgeois art market concerned with social distinction, moral temptations, and community ethos, the link between peasant imagery and the appreciation of Dutch historical vernacular culture has been less well studied. ${ }^{20}$

14 Not only was the figure of the peasant increasingly the subject of independent visual images (paintings and prints) in late-sixteenth-century Antwerp, but the customs of the peasant were also an important source for the writing of vernacular histories published in the city. Guicciardini and Ortelius would both refer to peasant costumes and customs as antique in origin and/or to ancient Netherlandish practices being like those of the contemporary peasant. Peasant culture, in much the same way as the Dutch language, could provide access to the past precisely where there was a local absence of texts or physical remains. The figure of the peasant was increasingly identified with a historical, even an antique, Dutch identity, in contradistinction to the increasingly urban character of the sixteenth-century Low Countries.

\section{Bruegel's Peasants and the Production of Local History}

15 Pieter Bruegel the Elder is perhaps the most famous artist to depict peasant life in the period, and his peasant scenes have been mined for allegorical, moralizing, and comedic readings, while little consideration has been given to the links between Bruegel's pictorial representation of peasants and the representation of peasant customs in contemporary historical, chorographical, and early ethnographic writings. ${ }^{21}$ In the remainder of this article, I will argue that the peasant, in both Bruegel's images and in sixteenth-century histories and ethnographies, was represented as an embodiment of vernacular history, a kind of living archaeological record, as well as a metaphoric 
vehicle for the transmission of a distinctly Netherlandish culture.

16 Bruegel's printed and painted peasants offer perhaps the most specific and tangible links to the broader interest in Dutch vernacular identity among Antwerp humanists. Hieronymus Cock's publishing house, De Vier Winden (The Four Winds), which published most of Bruegel's prints, had a parallel audience to that of Christopher Plantin's press - an educated and international clientele interested in high-quality products. ${ }^{22}$ Cock's prints were less expensive and more accessible than the more esoteric Latin texts of Plantin's press. The documented patrons for Bruegel's paintings mostly came from this broader audience, including civic administrators Jean Noirot and Niclaes Jonghelinck. ${ }^{23}$ Noirot and Jonghelinck probably had a working knowledge of Latin, but they were not necessarily as steeped in the classical tradition as a scholar like Ortelius.

17 It is important, however, to recognize the intellectual ambitions of Bruegel's clientele, rather than dismissing their acquisitions as merely "mercantile." In addition to sixteen paintings by Bruegel, Jonghelinck owned a series of panels depicting the Labors of Hercules by Frans Floris, as well as a series of bronzes by Floris's brother Jacques, depicting Bacchus and the seven planets. ${ }^{24}$ Merchants, too, could be interested in antiquity and local history, without acquiring classical Latin or Greek. The widespread popularity of Guicciardini's Descrittione di tutti i Paesi Bassi, which went through three editions in both French and Italian before 1590, also attests to the broader audience interested in a local vernacular customs and traditions. ${ }^{25}$

18 In addition to addressing a public that converged with that of the authors of local histories, dictionaries, and compilers of customs, Bruegel, perhaps most importantly, also shared these authors' methodological concern with observation and accurate description, as well as cultivating his own particular awareness of local painterly tradition. Bruegel's landscape prints have been connected to the contemporary philosophical interest in neo-Stoic principles, namely the Stoic ideal of detached observation of one's surroundings, as well as to contemporary chorographic texts that mix geographic description and historical analysis. ${ }^{26}$ Yet the artist's peasant scenes have not been discussed alongside similar historical texts that closely associate landscape with vernacular cultural traditions, particularly peasant customs.

19 The methodological link between history, custom, and geography was itself antique in origin. Aristotle, Cicero, and Quintilian all used the commonplace of altera natura (second nature) to describe the intimate connection between a people and their physical environment. ${ }^{27}$ Custom was understood as a natural phenomenon, linked to a particular topography and cultural history. In his Histories, Herodotus had singled out particular types of customs and practices for discussion: religious rites, burial practice, marriage customs, and diet. ${ }^{28}$ Ortelius, in his 1596 Aurei Saeculi Imago, or The Mirror of the Golden Age, divided his short guide to antique Belgo-German civilization into similar sections, each with their own accompanying illustration. ${ }^{29}$ Significantly, this inherited model of cultural description often foregrounded peasant culture. While the genealogies of European nobility merited inclusion in the cosmography, the diet, costumes, and customs of the peasant were described more often than the courtly lifestyle of the nobility.

20 Guicciardini, for example, devotes the second division of his Descrittione to the "quality, and costumes of the men and women" of the Low Countries, after his discussion of the region's geogra- 
phy and before a description of the region's political system. The "men and women" Guicciardini describes are most often villagers and/or peasants. After briefly mentioning the fashionable dress of the nobility, Guicciardini specifically draws attention to the vagaries of regional countryside costume, citing this variation as continuing "from the time of Julius Cesar." 30 In the same section of text, Guicciardini devotes considerable space to reporting the typical Netherlander's love of drink and feasting. Again, his examples are drawn from the lower orders, not from nobility - with the Italian famously claiming that the average Netherlander would travel twenty-five to thirty leagues to attend a kermis or wedding. ${ }^{31}$

21 In the early histories of the Low Countries, peasant custom took on particular importance as the antique Netherlanders, the Batavians, were consistently portrayed as "peasant-like."32 Described in Tacitus's Germania in a small section concerning the tribes of the Northern Rhine region, the Batavians are characterized as an agrarian people, though they are accomplished warriors. ${ }^{33}$ Tacitus describes the Batavians as living a pastoral existence, in contradistinction to urban Rome. The classical historian was avidly read in the sixteenth century and his style much copied. Germania was the antique source for the Batavian myth and Tacitus also provided the model for the writing of a non-Roman history. ${ }^{34}$

22 Aurelius, author of one of the first histories of the Low Countries, the famous Divieskroniek of 1517, based his depiction of the Arcadian, agricultural nature of Batavian society on Tacitus's account, writing, "many notable points have been written by Julius Caesar and Cornelis Tacitus that I would like to record in my chronicle" ${ }^{35}$ Hadrianus Junius's Batavia, which was probably finished in 1568 and was later published in Antwerp, was also directly modeled on Germania. ${ }^{36}$ In all of these texts, the Batavians are described as relative primitives compared to the civilized inhabitants of Rome. Yet this supposed primitivism is turned into a cultural asset, as a rural lifestyle is equated with honesty and simplicity. In perhaps the most famous example of this inversion, Erasmus's 1508 adage "On the Batavian Ear" turned Martial's epigram describing the ignorance of northern peoples into a celebration of the character of both the historical and contemporary Netherlanders. ${ }^{37}$

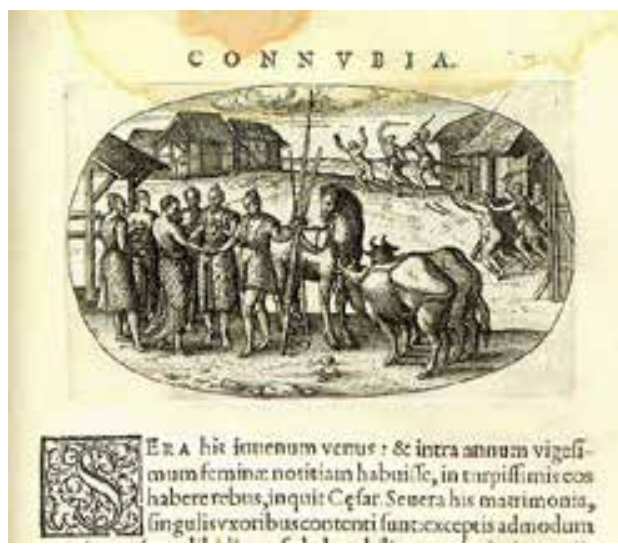

Fig 4. Pieter van der Borcht, Connubia, from Aurei Saeculi, 1596, engraving, $7 \times 11.4 \mathrm{~cm}$, London, British Library

23 The specific visual and textual connection between the contemporary peasant and the historical Netherlander appears to have been a device particularly embraced by Antwerp humanists. As noted above, Guicciardini claimed that Netherlandish peasant costume had remained unchanged since antiquity. In his illustration (fig. 4) for Ortelius's 1596 Aurei Saeculi, Pieter van der Borcht 
depicted an ancient German settlement as being similar to a sixteenth-century local rural community, with thatched roofs and predominately wooden architecture. ${ }^{38}$ Ortelius cites Caesar in noting that the diet of the ancient Belgo-Germans was based on meat, dairy, and bread. ${ }^{39}$ Aurelius described the Batavian diet as rich in meat and dairy, taking advantage of "rich pastures full of animals and...fruitful agricultural land." 40 This description of the Batavian diet and the bounty of the local landscape mirrors Erasmus's account of the Netherlandish love of feasting: "The reason for this [feasting] is, I think, the wonderful supply of everything, which can tempt one to enjoyment...partly due to the native fertility of the region, intersected as it is by navigable rivers full of fish, and abounding in rich pastures." ${ }^{11}$ Over fifty years later, Guicciardini would also single out the peasant's everyday consumption of bread, butter, and cheese, again attributing it to the abundance of the local landscape. ${ }^{42}$

24 Bruegel also paints a picture of a dairy- and beer-loving peasantry. In the Peasant Dance (fig. 5), for example, the artist includes a conspicuous mound of butter upon the table at left, alongside a half-eaten piece of bread and jugs of drink. ${ }^{43}$ Bruegel paid close attention to the vertical form of the butter, as well as to the small dish of salt next to it, and the various forms of ceramic drinking jugs used by the peasants. In their specificity these details parallel those offered by Guicciardini and Ortelius. Guicciardini, for example noted the contrast between the austere everyday diet of the Netherlandish peasant and the more sumptuous fare consumed on feast days. ${ }^{44}$ In Peasant Wedding (fig. 6), Bruegel indicates this richer peasant diet, complete with meat and rijstpap, which is shown being washed down by the copious amounts of beer poured by the peasant at far left. ${ }^{45}$

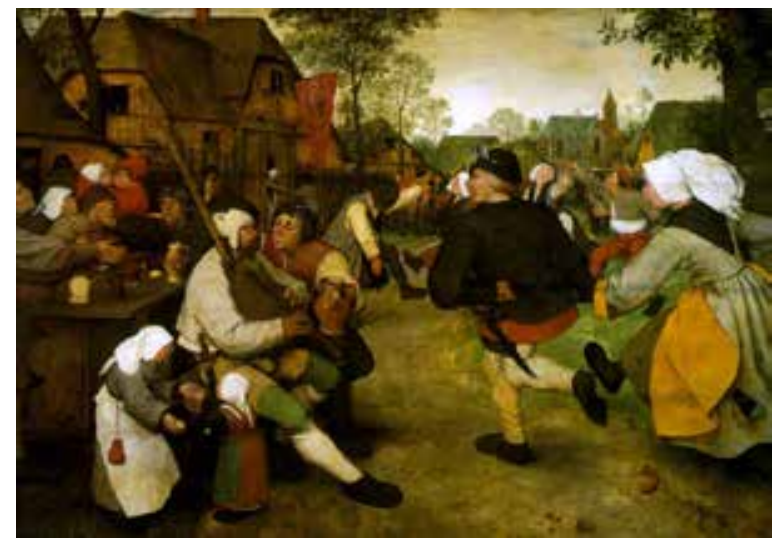

Fig 5. Pieter Bruegel, Peasant Dance, 1568, oil on panel, 114 x $164 \mathrm{~cm}$, Vienna, Kunsthistorisches Museum (artwork in the public domain)

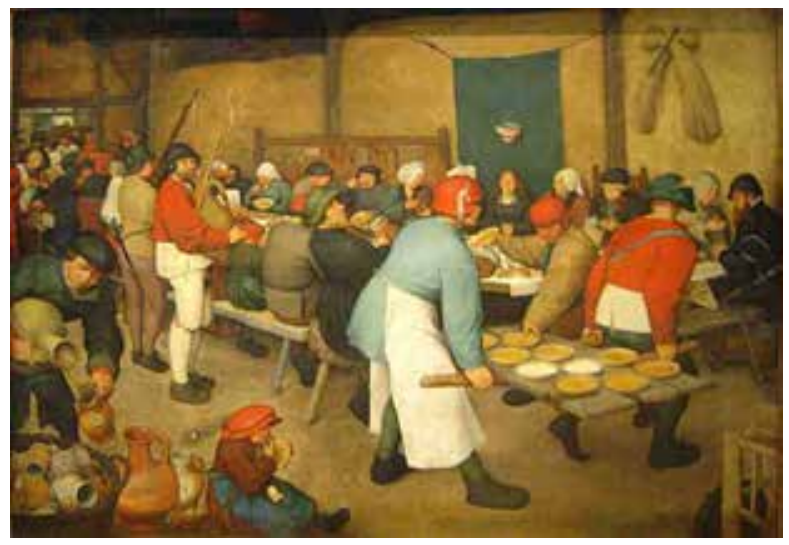

Fig 6. Pieter Bruegel, Peasant Wedding, 1568, oil on panel, $114 \times 164$ cm, Vienna, Kunsthistorisches Museum (artwork in the public domain)

Bruegel's wedding feast takes place inside a barn stacked high with straw, evoking the abundance of the local landscape. Van der Borcht's illustration of the ancient Germans feasting in the Aurei Saeculi (fig. 7) is reminiscent of Bruegel's image, ${ }^{46}$ as both picture celebrants drinking heavily and dining on bread as well as a kind of porridge. In van der Borcht's engraving, the feasting Belgo-Germans are seated outside and the artist includes a landscape view. The juxtaposition of feasting peasants, the fertile landscape, and the bounteous foodstuffs of the Low Countries also occurs in Bruegel's Peasant Wedding. 


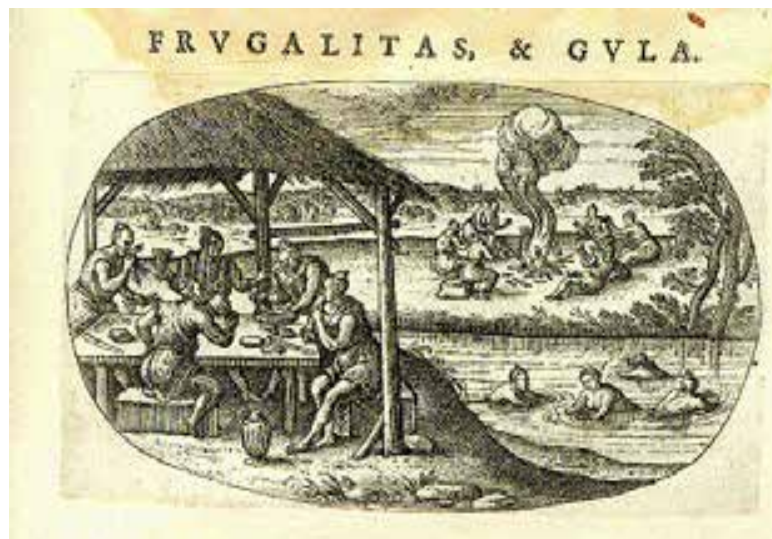

Fig 7. Pieter van der Borcht, Frugalitas and Gula, from Aurei Saeculi, 1596, engraving, $7 \times 11.4 \mathrm{~cm}$, London, British Library (artwork in the public domain)

26 The conviviality of the Netherlandish people at weddings and other festive occasions was also often cited by authors describing the Low Countries of antiquity and of the sixteenth century. Erasmus admitted that the Netherlandish race was prone to excess but qualifies this vice, stipulating: "If you look to the manners of everyday life, there is no race more open to humanity and kindness." ${ }^{37}$ Ortelius's description of the ancient German peoples also stressed their hospitality ("hospitijs auc convictibus"), as well as their propensity for excessive drinking ("continuare potando nulli probrum"). ${ }^{48}$ Aurelius described the Batavians in a similar fashion..$^{49}$ Guicciardini writes that the Netherlander's "vice is drinking to excess... but this is somewhat excusable because the air of the country is most of the time humid and melancholic." ${ }^{50}$ The festivity of the Netherlandish peasant is consistently described as both a contemporary and a historical phenomenon.

27 Bruegel's particular interest in the diet and customs associated with weddings parallels that of contemporary cosmographers or collectors of customs. The artist's peasant wedding scenes include a number of specific details related to local marriage customs. In the Peasant Dance these include: the crown hanging above the bride's head, the commemorative ribbons adorning the bagpipers' instruments, and the color of the rich saffron porridge, to name just a few prominent examples. ${ }^{51}$ These are the kinds of culturally-specific details found in contemporary ethnographic collections and histories. Aurelius and Ortelius, for example, both describe the specific exchange of gifts (arms and animals) in the Batavian marriage ceremony. ${ }^{52}$ Both Bruegel and the historian are interested in the particulars of these practices, making a claim either to firsthand observation or to direct sources who described such behavior. ${ }^{53}$

28 Bruegel's peasant pictures not only reproduce specific, observed practices but also painstakingly describe the material life of everyday things. In the Peasant Wedding Bruegel carefully articulates the grooved indentations and variegated colors of the assortment of drinking jugs held in the basket at the bottom left. The artist includes details, such as the makeshift tray made from an unhinged door or the large upturned tub acting as a seat for the well-dressed man at far right, that seemingly attest to witnessed practice. ${ }^{54}$ The artistic deliberation and specificity of detail mirrors that of Ortelius, who describes the various types of dwelling inhabited by the ancient Belgo-German in Aurei Saeculi, and by Guicciardini's numerous lists (including those of rivers, forests, walled towns, and villages) in the Descrittione. Both authors and the artist claim authority as compilers of information. Ortelius primarily cites authors from antiquity - Tacitus, Caesar, and Pliny. Guicciardini draws upon the same authors but also upon his own careful observations and 
firsthand research, which he revised and expanded in the numerous editions of the Descrittione. Bruegel's images, in their attention to material detail, appear to replicate Guicciardini's methodological claims.

The methodological connection between Bruegel's images and contemporary histories and collections of customs extends beyond a shared interest in everyday experience. The artist and contemporary cultural historians emphasize particular moments within cultural life: childhood (Children's Games), feasts (Peasant Wedding, Kermesse at Hoboken), religious customs (Battle between Carnival and Lent), costume (Peasant Dance, Ice Skating outside St. George's Gate), and weddings (Peasant Wedding, Peasant Wedding Dance). Nearly all of Bruegel's peasant pictures take one of these topoi as subject, and these are precisely those areas described by Ortelius, Guicciardini, and other early historians.

30 In all of these textual accounts peasant culture is constructed both as "ancient" and as different from that of the urban, literate populace who consumed these early cosmographies, histories, and collections of customs. Peasant custom is understood as an unchanging type of historical remnant, a contemporary and observable example of a primitive culture. Within his images of contemporary peasants Bruegel repeatedly includes details and practices that are often specifically discussed as historical survivals in contemporary texts (such as costume, vernacular architecture, feasting practices) and pays them particular attention. The audience for Bruegel's peasant paintings likely had some exposure to texts like Guicciardini's, as well as to other early histories and collections of customs that described peasant culture as historic, which would have shaped their understanding of the artist's peasant scenes. The peasant, as pictured by Bruegel, could simultaneously operate as contemporaneous "other" and as historical figure.

31 Antwerp humanists did not invent the concept of the peasant as historical remnant - again, it is a trope dating back to antique thought, perhaps best summarized by the classical proverb "Nemo sic mores vetustos estimat ut rusticus (No one keeps old customs like a peasant)." 55 The peasant represents a repository of old, and possibly forgotten, customs, in the face of a rapidly changing environment. As we have seen, sixteenth-century authors drew upon this proverbial knowledge of the peasant in diverse ways: collectors of customs and costumes turned to the peasant as subject, while cosmographers and chorographers often used peasant practice as a point of comparison, a way to describe ancient mores. Contemporary collections of customs may not have provided a direct model for Bruegel's pictorial practice, but both the historian and the artist share a methodological interest in certain "markers" of culture - particularly the diet, costume, and festive customs of the peasantry.

\section{Inventing History}

32 Reinhart Koselleck, one of the great modern explicators of the emergence of a concept of history and historical change, here provides us with a useful observation on the relationship between time, history, and cultural difference, drawn from his analysis of the historical thought of the Hellenic world. Koselleck remarks that the difference between the barbarian (the non-Greek) and the Greek or Hellene is that the Hellene used to be like the barbarian. The barbarians' contemporaneousness is perceived in terms of their noncontemporaneous cultural level. ${ }^{56}$ In other words, the "other" is presented as the pre-evolved state of the dominant culture. Koselleck's formulation 
demonstrates how contemporary cultural differences are constructed within a historical perspective and given a temporal dimension. Guicciardini's assertion that Netherlandish rural dress had remained unchanged since antiquity or van der Borcht's imagining of ancient Belgo-German settlements as being like peasant villages reveals a basic assumption about peasant culture as fundamentally static, in contrast to the evolved culture of the urban populace.

33 So, whereas the town-dweller belongs to a civilization with its own history, peasants and primitives do not have a history; instead they represent the prehistorical state of "civilized" man. When early explorers encountered the native peoples of America, Asia, and Africa, their touchstone for comparison was always the European peasant. ${ }^{57}$ The peasant, like the "savage," remained untouched by the technological and social "advances" of urban Europe and was a living embodiment of Renaissance Europe's own cultural past. Rural society was perceived as temporally immobile, exhibiting a way of life unchanged since antiquity, because of the supposed impossibility of social progression within peasant life. ${ }^{58}$ In comparison with the rapid growth of urban, socially mobile middle-class populations in the Low Countries, the sixteenth-century peasant was seen by his contemporaries as existing within a vacuum of time.

34 This characterization of the peasant as a temporally immobile figure was part of a broader process of social distancing that occurred between the subject of these images and the middle to upper-class viewer. The peasant operated as both a negative and positive model of behavior ${ }^{59}$ and was utilized both as a living link to the Arcadian past and as a reminder of contemporary social distinctions. For example, when the 1561 Haagspel, the secondary contest within the larger rhetorical competition known as the Landjuweel, posed the question of which underrated occupation was the most useful and honest, the unanimous response was agriculture. ${ }^{60}$ Although the guise of the peasant could be used to represent virtuous Arcadian abundance, in many of these same processions and plays the contemporary peasant was satirized as a figure of crude excess and exuberance. ${ }^{61}$ Bruegel's images may celebrate the historical continuity of Dutch vernacular customs, but they also delight in the rough features and lumpy bodies of the peasantry.

35 Despite the symbolic temporal and social immobility of the peasantry in contemporary discourse, socioeconomic circumstances meant this static image of the peasantry was increasingly a fiction. In Bruegel's lifetime, many peasants came to the city for employment, and the countryside was drastically altered by the effects of cottage industries like linen production, as well as by the colonization of the rural landscape by wealthy owners of the country villas called spelhuizen. ${ }^{62}$ Outside of cities, new technologies allowed for vast land reclamation, construction and drainage projects that were completed largely through the use of peasant labor. ${ }^{63}$ Yet the peasantry's nonagricultural labor is conspicuously absent from Bruegel's images, which primarily focus on the traditional labors of the months, for the most part unchanged for centuries, and festive practices perceived to be ancient in origin.

36 Peasant culture was seen as historic but as having no history of its own. Therefore, it was possible to collapse the distance between, say the diet and costume of the ancient Batavians and that of the contemporary peasants of Brabant, as does Guicciardini, or between the vernacular architecture of the ancient Germans and that of the contemporary Netherlandish peasant, as does Ortelius. Because peasant life was seen as unchanging (having no historical evolution of its own), it could 
be used as a substitute for the past.

37 Reflecting this curious temporal condition, Bruegel's peasant pictures engage with history in a different way than the customary painting of historia. Bruegel did paint a number of pictures that meet the Leon Battista Alberti's conception of historia - for example, the Massacre of the Innocents, Christ Carrying the Cross, and The Suicide of Saul. But the paintings under discussion here are different: although they are of the large scale typically associated with history painting, they are non-narrative, nonhistorical genre scenes. The subjects of these pictures do not derive from any specific classical or biblical text, their authority comes rather from the depiction of practices rooted in cultural tradition and the shared experience of the community. In The Battle between Carnival and Lent, for example, Bruegel displays a variety of costumes and customs that range from street performance and the cooking of waffles over a fire to the masked and stuffed bellies of carnival revelers. This Rabelaisian abundance of details calls upon the viewer's own experience and the picture's own internal logic to such great effect that Bruegel's pictures are understood as authoritative documentary material and still used to illustrate histories of carnival customs. ${ }^{64}$ Bruegel and the contemporary cosmographer or historian, as well as the collector of customs, all used this type of unauthored and communal authority as an unwritten source of historia.

38 Bruegel's specific attention to peasant custom in panels of a size typically reserved for history painting parallels the burgeoning appreciation for the representation of historic peasant culture. Bruegel depicts peasant practice on a monumental scale, granting humble vernacular customs pictorial status equal to that of antiquity or biblical history. In a similar fashion, Ortelius and Guicciardini include descriptions of marriage customs and diet, laws and family life, the latter alongside royal lineages and traditional histories, in their representation of various populations. The living and breathing culture of the everyday is integrated into the fabrication of history.

39 In Ortelius's map of Brittenburg, the example with which I began this essay, the peasant also mediates between the physical remains of the past and the historical knowledge of the present. The contemporary peasant and the antique past are brought into contact through the discovery and manipulation of archaeological remains, as well as through their own lived experience and vernacular traditions. In both pictorial and textual representations, the peasant acted as a metaphoric vehicle, a type of living archaeological record and an embodiment of local history.

40 Bruegel's innovation as an artist was to take subject matter that had existed, perhaps in other media, such as prints and decorated domestic objects, as well as in cheaper types of painting such as linen painting, into the medium of oil painting, marketing it to the upper middle classes who were interested in local custom, both as a source of amusement and as a historic vehicle. ${ }^{65}$ Bruegel was also interested in the continuity of historical artistic practice, transposing painting techniques derived from the local tradition of linen painting into the medium of oil and the skills of a miniature painter to a larger scale. ${ }^{66}$ The result was his own distinct painterly idiom, capable of producing paintings composed both of broad strokes and minute detail. Bruegel thus not only displays historical cultural practices in panels like Peasant Wedding or Battle between Carnival and Lent, as collected and described by sixteenth-century ethnographers and historians, he also paints these customs in a self-conscious mixture of traditional painting styles. Just as peasant culture can be seen as historical, so can the way Bruegel depicts peasant practice, in paintings on the scale of 
history paintings and in a style faithful to longstanding local practice.

41 Crucially, Antwerp was the primary center for the production of both vernacular peasant imagery and the numerous maps, dictionaries, and histories of the Low Countries - many of which, like Ortelius's map of Brittenberg, explicitly referred to peasants and/or peasant custom. The link between a historical agrarian population and the contemporary peasantry was also apparently unique to historical representations of the Low Countries, although the concept of the "primitive" was key to both German and English sixteenth-century histories. ${ }^{67}$ While the interest in collecting customs and costumes was part of a pan-European interest in the local, and the fascination with the antique history of Northern Europe was indebted to the broader resurgent popularity of Tacitus's Germania, it was in Antwerp where the production of a uniquely "Netherlandish" vernacular history and cultural identity would take hold.

42 Instead of reconstructing a narrative history showing how Bruegel's images of peasants and contemporary histories and collections of costumes influenced and quoted each other, I have proposed here a more nebulous relation, closer to the definition of a network, as recently proposed by Krista De Jonge, whereby influence travels in multiple directions and flows in successive currents. ${ }^{68}$ The idea of the peasant as a historic remnant had a particular cultural currency in the later sixteenth-century Low Countries that was centered around the intellectual output of the Antwerp humanists but was also felt in rival civic centers (for example Nijmegen) and extended beyond a narrow academic circle. Bruegel's own move to Brussels in 1563 did not mean he was removed from an interest in vernacular history or, indeed, from similarly concerned clients and friends in Antwerp, such as Jonghelinck or Ortelius.

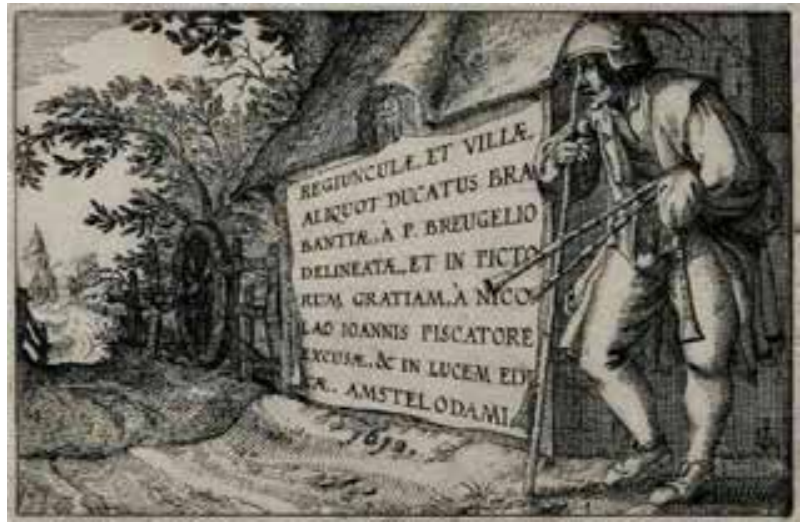

Fig 8. Claes Jansz Visscher, Title page, from Regiunculae, et Villae Aliquot Ducatus Brabantiae..., 1612, etching, $10.5 \times 15.5 \mathrm{~cm}$. British Museum, London, 1936,116.4

43 Peasant imagery represented a particular strain of Antwerp's networked production of a vernacular culture - a product that proved so successful it would lead to the establishment of an industry devoted to the Bruegelian peasant image in the years following the Dutch Revolt. In the years after 1600, the Bruegelian peasant scene would itself become the subject of a nostalgic glance backwards and the production of a new Dutch vernacular. The Amsterdam publisher Claes Jansz. Visscher, in the 1612 title page for his condensed series of re-etched copies after the uncredited Small Landscapes (fig. 8) originally published in 1559 and 1561 by Hieronymous Cock, neatly pictures this relation. ${ }^{69}$

44 The series of Brabantine countryside landscapes, which Visscher claims were drawn from life, 
have been reattributed to Bruegel and a suitably Bruegelian bagpiper is positioned next to the series' new descriptive title. Published in the Northern Netherlands after the devastating and protracted war with the Spanish, these image of the pre-war Flemish countryside would evoke nostalgic recollections of a lost past and place for the thousands of émigrés to the newly established Dutch republic in the north. Yet this image of the historic Flemish past and the Brabantine landscape is bound to the figure of the peasant, as pictured by Bruegel fifty years earlier. Despite the fact the Small Landscapes were not the inventions of Bruegel, it is Bruegel's peasants, perhaps unsurprisingly, who have become synonymous with a historic Flemish local identity.

\section{Acknowledgements}

I would like to thank Ethan Matt Kavaler and Todd Richardson for including a shorter version of this essay in their session "Antwerp and Its Boundaries, 1550-1570" at the 2010 Historians of Netherlandish Art conference, as well as the two anonymous readers for the JHNA for their incisive comments.

After receiving her Phd from the Courtauld Institute in 2009, Stephanie Porras was the Leibniz-Gemeinschaft Postdoctoral Fellow at the Courtauld and the Germanisches Nationalmuseum, Nuremberg. She is currently a Mellon Postdoctoral Fellow at Columbia University.

\section{List of Illustrations}

Fig 1. Anonymous German, Map of Holland, from Sebastian Münster, Cosmographiae universalis, 1550, fol. 513, woodcut, $25.3 \times 17.4 \mathrm{~cm}$, London, British Museum (artwork in the public domain)

Fig 2. Abraham Ortelius, Arx Britannica, 1566-68, engraving, 32.4 x $23.2 \mathrm{~cm}$, London, British Library (artwork in the public domain)

Fig 3. Johannes and Lucas van Doetecum (after Pieter Bruegel), Kermis at Hoboken, 1559, engraving, 32.7 x $51.6 \mathrm{~cm}$, London, British Museum (artwork in the public domain)

Fig 4. Pieter van der Borcht, Connubia, from Aurei Saeculi, 1596, engraving, 7 x $11.4 \mathrm{~cm}$, London, British Library (artwork in the public domain)

Fig 5. Pieter Bruegel, Peasant Dance, 1568, oil on panel, 114 x 164 cm, Vienna, Kunsthistorisches Museum (artwork in the public domain)

Fig 6. Pieter Bruegel, Peasant Wedding, 1568, oil on panel, 114 x $164 \mathrm{~cm}$, Vienna, Kunsthistorisches Museum (artwork in the public domain)

Fig 7. Pieter van der Borcht, Frugalitas and Gula, from Aurei Saeculi, 1596, engraving, 7 x 11.4 $\mathrm{cm}$, London, British Library (artwork in the public domain)

Fig 8. Claes Jansz Visscher, Title page, from Regiunculae, et Villae Aliquot Ducatus Brabantiae . 
.., 1612, etching, $10.5 \times 15.5 \mathrm{~cm}$. British Museum, London, 1936,116.4 (artwork in the public domain)

${ }^{\star}$ All translations are the author's unless otherwise noted.

${ }^{1}$ Cornelis Aurelius, Die cronycke van Hollandt, Zeelandt en Drieslant (Leiden: Jan Seversz., 1517). Chapter 13 (first division) discusses the site and the links to Britain. On the importance of the site in the early history of the Low Countries, see Wilfried Hessing, "Foreign Oppressor versus Civiliser: The Batavian Myth as a Source for Contrasting Associations with Rome in Dutch Historiography and Archaeology," in Images of Rome: Perceptions of Ancient Rome in Europe and the United States in the Modern Age, ed. Richard Hingley ( = Journal of Roman Archaeology, supplement, 2001), 135; Karen Tilmans, Historiography and Humanism in Holland in the Age of Erasmus: Aurelius and the Divisiekroniek of 1517, trans. Sam Herman (Nieuwkroop: De Graaf, 1992), 135. A summary of current archaeology on Katwijk can be found in J. E. A. Boomgaard, et al., ed., De uitwateringssluizen van Katwijk 1404-1984, vol. 13 (Leiden Hollandse Studiën, 1984). ${ }^{2}$ Sebastian Münster, Cosmographiae universalis (Basel: Henri Petri, 1550), 513.

${ }^{3}$ British Museum, C.9.D.4. On Ortelius's map, see Alain Schnapp, The Discovery of Time: The Origins of Archaeology, trans. Ian Kinnes and Gillian Varndell (London: British Museum Press, 1996), 139; J. H. F. Bloemers and M. D. de Weerd, "Van Brittenburg naar Lugdunum," in De uitwateringssluizen van Katwijk, 48; R. W Karrow, "Abraham Ortelius: Een introductie," in Abraham Ortelius: Cartograaf en humanist, ed. Pierre Cockshaw, et al. (Turnhout, Antwerp, and Brussels: Brepols, Museum Plantin-Moretus, and Koninklijk Bibliotheek im België, 1998), 26; Tine Luk Meganck, "Erudite Eyes: Artists and Antiquarians in the Circle of Abraham Ortelius (1527-1598)" (PhD diss., Princeton University, 2003), 27.

${ }^{4}$ On May 8, 1566, Guido Laurinius wrote to Ortelius about the site, referring to inscriptions given to Ortelius by Hubertus Goltzius, who according to Laurinius had "oude marmeren steen van de Arx Britannica gecopieerd." See J. H. Hessels, Abrahami Ortelii epistulae (Cambridge: Typis Academiae, 1887), 34-36.Tine Luk Meganck has argued therefore that all three were working on the map in the period 1566 to 1568 , when a payment in the archives of the Plantin press records payment for the printing of a map of the Arx Britannica to take to the Frankfurt fair. See Tine L. Meganck, "Abraham Ortelius, Hubertus Goltzius en Guido Laurinus en de studie van de Arx Britannica," Koninklijke Nederlandse Oudheidkundige Bond 98, no. 5/6 (1999): 226-36. The Plantin record, referring to "In Martio 1568. Francofordiae. 'Arx Britannica' st. 7" can be found in Jan Denucé, Oud-Nederlandse Kaartmakers in betrekking met Plantijn (Amsterdam: Meridian, 1964), 2:161.

${ }^{5}$ Published in the Netherlands as: Lodovico Guicciardini, Description de tout le Païs bas (Antwerp: William Silvius, 1567), 243-44.

${ }^{6}$ Francis Haskell, History and Its Images: Art and the Interpretation of the Past (New Haven and London: Yale University Press, 1993), 111.

${ }^{7}$ Guicciardini, Description, 243-44.

${ }^{8}$ See, for example, the 1550 Nederlandsche spellynghe published in Ghent by Joas Lambrecht and Anton t'Sestich's 1576 work Orthographia Linguae Belgicae. For a compendium of Dutch dictionaries of the period, see F. Claes, Lijst van Nederlandse woordenlijsten en woordenboeken gedruckt 
tot 1600 (Nieuwkoop: B. de Graaf, 1974), as well as Pieter Geyl, The Revolt of the Netherlands 1555-1609 (London: Ernest Benn, 1966), 273.

${ }^{9}$ Cornelis van Ghistele, Deerste sesse boecken van Aeneas (Antwerp, 1556), f. $\pi 4 \mathrm{r}$. I am grateful to an insightful paper given by Femke Hemelaar at the conference Understanding Art in Antwerp, 1540-1580: Classicizing the Popular, Popularizing the Classic, Groningen Research School for the Humanities, Groningen, Netherlands, January 23-24, 2008, for bringing van Ghistele's work to my attention.

${ }^{10}$ Author's foreword in Jan van der Werve, Het Tresoor der Duytsscher Talen (Antwerp: Hans de Laet, 1553).

${ }^{11}$ This phenomenon was not limited to the Dutch but was experienced across Europe. See JeanClaude Margolin, "Science et nationalisme linguistique ou la bataille pour l'étymologie au XVI siècle," in TheFairest Flower: The Emergenceof Linguistic National Consciousness in Renaissance Europe, International Conference of the Center for Medieval and Renaissance Studies, University of California at Los Angeles, December 12-13, 1983 (Florence: Presso l'Academia della Crusca, 1985),139-65. In his recent book, Walter Gibson discusses the emergence of such "linguistic nationalism" as a key factor in the popularity of proverb imagery in the Low Countries. See Gibson, Figures of Speech: Picturing Proverbs in Renaissance Netherlands (Berkeley, Los Angeles, and London: University of California Press, 2010), 13-17. See also the foundational study of the development of the Dutch vernacular, L. van den Branden, Het Streven naar verheerlijking, zuivering en opbouw van het Nederlands in de 16de eeuw (Ghent: Koninklijke Vlaamse Academie voor Taal- en Letterkunde, 1956).

${ }^{12}$ Jeroen Jansen, "Purity and the Language of the Court in the Late Sixteenth and SeventeenthCentury Netherlands," in The Vulgar Tongue, ed. Fiona Somerset and Nicholas Watson (Philadelphia: Penn State Press, 2003), 166-70.

${ }^{13}$ See Johannes Gropius Becanus, Origines Antwerpianae (Antwerp: Plantin, 1569). This claim was by no means universally accepted, however, and would be derided later by Justus Lipsius and Joseph Justus Scaliger. See Lipsius's letter to Hendrik Schotti in Lipsius, Epistolarum selectarum centuria prima ad Belgas (Antwerp: Moretus, 1602 ), which disputes such an attempt to reconstruct a speculative history of the Dutch language. Scaliger's attack on Becanus was even more direct: "Never have I read greater nonsense, never have I seen or heard greater irresponsibility (Nunquam legi maiores nugas, nunquam insigniorem temeritatem vidi neque audivi). " See "Castigationes," in Julius Caesar Scaliger, M. Verrrii Flacci quae extant. Et Sex. Pompeii Festi de verborem significatione libri xx (Paris: M. Patissonum, 1576): xvi.

${ }^{14}$ Becanus's Origines Antwerpianae was the first such account of the Dutch language, though histories of other European languages, such as Claude Tolomei's 1555 work on the history of Italian, Il Cesano: De la lingua toscana, had appeared earlier.

${ }^{15}$ See Becanus, Origines Antwerpianae, and Petrus Divaeus, De galliae beligicae antiquitatibus, (Antwerp: Plantin, 1584). Divaeus's work was first published in Simons Schardius, Rerum germanicarum scriptures varii (Frankfurt, 1565).

${ }^{16}$ The first two books are reproduced in J. C. M. Riemsdijk, "De twee eerste musyckboekskens van Tielman Susato: Bijdrage tot het Nederlandsch Volkslied in de 16de eeuw," Tijdschrift der Vereeniging voor Noord-Nederlands Muziekgeschiedenis 3, no. 2 (1888): 61-110. See also Musyck boexken:Dutch Songs for Four Voices, ed. Timothy McTaggert (Madison, Wis.: A-R Editions, 1997).

${ }^{17}$ Symon Andriessoon, Duytsche Adagia ofte spreecwoorden, ed. Mark Meadows and Anneke C. 
G. Fleurkens (Hilversum: Verloren, 2003 [originally published in 1550]).

${ }^{18}$ On the Kermis of Hoboken, see: A. Monballieu, "De 'Kermis van Hoboken' van P. Bruegel, J. Grimmer en G. Mostaert," Jaarboek van het Koninklijk Museum voor Schone Kunsten (1974): 139-69; Hans Mielke, Pieter Bruegel: Die Zeichnungen (Turnhout: Brepols, 1996), no. 44 ; Nadine M. Orenstein, ed., Pieter Bruegel the Elder: Drawings and Prints (New Haven, New York, and London: Metropolitan Museum of Art and Yale University Press, 2001), no. 80.

${ }^{19}$ Michel de Montaigne would be an advocate of this view of custom. See William J. Bouwsma, The Waning of the Renaissance, 1550-1640, (New Haven and London: Yale University Press, 2000), 47.

${ }^{20}$ On the rise of the peasant genre in Antwerp, see Larry Silver, Peasant Scenes and Landscapes: The Rise of Pictorial Genre in the Antwerp Art Market (Philadelphia: University of Pennsylvania Press, 2006), chapter 6 . Silver argues that these images are based upon social distancing, but that, with the innovations of Pieter Bruegel the Elder, they become considerably more tolerant and aimed at amusing rather than exposing sinful behavior. Two foundational studies on peasant imagery as satire and as a vehicle for social distinction are Hans-Joachim Raupp, Bauernsatiren: Entstehung und Entwicklung des bäuerlichen Genres in der deutschen und niederländischen Kunst ca. 1470-1570 (Niederzier: Lukassen, 1986), and Paul Vandenbroeck, Beeldvan de andere, vertoog over het zelf (Antwerp: Koninklijk Museum voor Schone Kunst, 1987).

${ }^{21}$ The literature on Bruegel's peasant scenes is vast, but three relatively recent monographs on the artist discuss the satiric, comedic, and socioeconomic readings of Bruegel's images: Margaret A Sullivan,Bruegel's Peasants: Art and Audience in the Northern Renaissance (Cambridge: Cambridge University Press, 1994), Ethan Matt Kavaler, Pieter Bruegel: Parables of Order and Enterprise (Cambridge: Cambridge University Press, 1999), and Walter Gibson, Pieter Bruegel and the Art of Laughter (Berkeley, Los Angeles, and London: University of California Press, 2006). For a fascinating discussion of the interrelation between Bruegel's peasant scenes and contemporary chorographies, see Nils Büttner, Die Erfindung der Landschaft: Kosmographie und Landschaftskunst im Zeitalter Bruegels (Göttingen: Vandenboeck and Ruprecht, 2000). In some respect, my own research seeks to take similar source material on the history and geography of the Low Countries as it was being written in the sixteenth century and apply it to Bruegel's peasant scenes. 22 Timothy Riggs, "Hieronymus Cock: Printmaker and Publisher" (PhD diss., Yale University, 1971), 207-11. Plantin also often sold prints for Cock overseas alongside his international book shipments, see A. J. J. Delen, Histoire de la gravuredans les anciens Pays-Bas et dans les provinces belges (Paris: Les Ėditions d'Art et d'Histoire, 1935), 2:151-53.

${ }^{23}$ Although it is known that Abraham Ortelius owned one small grisaille by the artist and that the renowned art collector Cardinal Granvelle owned a number of works by Bruegel, in terms of numbers of pictures owned, Bruegel's "typical” clientele are considered to be Antwerp patrons from the mercantile class like Noirot and Jonghelinck.

${ }^{24}$ On the paintings collection of Niclaes Jonghelinck, see Iain Buchanan, "The Collection of Niclaes Jongelinck: I. 'Bacchus and the Planets,'” Burlington Magazine 132, no. 1043 (1990): 102-13; and Iain Buchanan, "The Collection of Niclaes Jongelinck: II. The 'Months' by Pieter Bruegel the Elder," Burlington Magazine 132, no. 1049 (1990): 541-50.

${ }^{25}$ See Herman De La Fontaine, “The History of Guicciardini's Description of the Low Countries," Quaerendo 12, no.1 (1982): 22-51.

${ }^{26}$ See Justus Müller-Hofstede, “Zur Interpretation von Bruegels Landschaft: Äesthetischer Landschaftsbegriff und Stoische Weltbetrachtung," in Pieter Bruegel und seine Welt, ed. Otto Georg 
von Simson and Matthias Winner (Berlin: Mann, 1979), 73-142; and Buttner, Die Erfindung der Landschaft.

${ }^{27}$ Donald R. Kelley, “Altera Natur: The Idea of Custom in Historical Perspective”, in New Perspectives on Renaissance Thought: Essays in the History of Science, Education and Philosophy, ed. John Henry and Sarah Hutton (London: Gerald Duckworth, 1990), 83-92. Larry Silver has written a compelling article about how Renaissance German writers and artists conceived of Germanic identity as being connected to the forest, directly linking national identity, tradition, and the physical environment. See Larry Silver, "Forest Primeval: Albrecht Altdorfer and the German Wilderness Landscape," Simiolus 13, no. 1 (1983): 4-43.

${ }^{28}$ Margaret T. Hogden, Early Anthropology in the Sixteenth and Seventeenth Centuries (Philadelphia: University of Pennsylvania Press, 1964), 23.

${ }^{29}$ Abraham Ortelius, Aurei Saeculi Imago sive germanorum veerum vita, mores, ritus \& religio (Antwerp: P. Galle, 1596). For a Dutch translation of the text, see Aurei Saeculi Imago of Spiegel van de Gouden Tijd, ed. Joost Depuydt and Jeanine De Landtsheer (Wildert: De Carbolineum, 1999).

${ }^{30}$ Guicciardini, Description, 39.

${ }^{31}$ Guicciardini, Description, 39.

${ }^{32}$ For an overview of the historical understanding of the Batavians, see Sandra Langereis, "Van bote boeren tot beschaafde burgers: Oudheidkundige beelden van de Bataven 1500-1800," in De Bataven verhalen van den verdwenen volk, ed. Louis Swinkels (Amsterdam and Nijmegen: De Bataafsche leeuw and Museum Het Valkhof, 2004), 72-108.

${ }^{33}$ Tacitus, The Agricola and the Germania, trans. H. Mattingly (London: Penguin, 1970), 25, 109.

${ }^{34}$ I. Schöffer, "The Batavian Myth during the Sixteenth and Seventeenth Centuries," in Britain and the Netherlands V, ed. J. S. Bromley and E. H. Kossmann (The Hague: Martinus Nijhoff, 1975), 87. Although there was not a definitive and complete Dutch translation of Tacitus until the early seventeenth century, translations were available in German (1526), Italian (1544), and French (1548). On the history of vernacular translations of Tacitus, see Else-Lily Etter, Tacitus in der Geistgeschichte des 16. und 17. Jahrhunderts (Basel and Stuttgart: Helbing \& Lichtenhahn, 1966). 35 "vele notabele puncten die Julius cesar en cornelius tacitus bescreven hebben / aldus will ic dat hier mede in dese cronike insereren," in Die cronycke van Hollandt, fol. 11r. For a discussion of Aurelius's citation of Tacitus, see Tilmans, Historiography and Humanism, 252; and Karin Tilmans, "Aeneas, Bato and Civilis, the Forefathers of the Dutch: The Origins of the Batavian Tradition in the Dutch Humanistic Historiography," in Renaissance Culture in Context: Theory and Practice, ed. Jean R. Brink and William F. Gentrup (Aldershot: Scholar Press, 1993), 131. ${ }^{36}$ Dirk van Miert, "La Batavia de Adriano Junio (1511-1575)," in Humanismo y pervivencia del mundo clásico: Homenaje al profesor Antonio Fontán, ed. José Maestere Maestere, et al. (Madrid: Instituto de Estudios Humanísticos-CSIC, 2002), 114.

${ }^{37}$ Martial's epigram reads: “'Tune es, tune, ait, 'ille Martialis cuius nequitias iocosque novit aurem qui modo non habet Batavam?'”: Epigrams, trans. James Michie (New York: Modern Library, 2002),6:82. The English translation of Erasmus's adage is from Margaret Mann Phillips, ed. and trans., The 'Adages' of Erasmus: A Study with Translations (Cambridge: Cambridge University Press, 1964), 209-12. On Erasmus and the Batavians, see M. E. H. N. Mout, “Het Bataafse Oor' De lotgevallen van Erasmus' adagium 'Aurij Batava' in de Nederlandse geschiedschrijving," Koninklijk Nederlandse Akademie van Wetenschappen 56, no. 2 (1993); Ari Wesseling, "Are the Dutch Uncivilised?': Erasmus on the Batavians and His National Identity," Erasmus of Rotterdam Society Yearbook 13 (1993): 68-102; István Bejczy, "Drie humanisten en een mythe de betekenis van 
Erasmus, Aurelius en Geldenhouwer voor de Bataafse kwestie," Tijdschrift voor Geschiedenis 109, no. 4 (1996): 467-84; and István Bejczy, "Erasmus Becomes a Netherlander," Sixteenth-Century Journal 28, no. 2 (1997): 387-99.

${ }^{38}$ Guicciardini, Description, 38; Münster, Cosmographiae, 326.

39 "Maiorem partem victus in lacte, carne, \& caseo consistere, docet Caesar": Ortelius, Aurei Saeculi Imago, B3.

40 "goede weiden vol van beesten ende... seer vruchtbar ende wasbaer van saeylant": Die cronycke van Hollandt, fol. 91r.

${ }^{41}$ The 'Adages' of Erasmus, 211.

${ }^{42}$ Lodovico Guicciardini, Description, 37-39.

${ }^{43}$ A selection of recent literature on the panel, in the Vienna Kunsthistorisches Museum, includes: Walter S. Gibson, "Some Notes on Pieter Bruegel the Elder's Peasant Wedding Feast," Art Quarterly 28, no. 3 (1965): 194-208; Müller-Hofstede, "Zur Interpretation von Bruegel's Landschaft, Äesthetischer Lanschaftsbegriff und stoische Weltbetrachtung," 141-42; Raupp, Bauernsatiren, 278-81, 283-87, 290-92 ; Margaret D. Carroll, "Peasant Festivity and Political Identity in the Sixteenth Century," Art History 10, no. 3 (1987): 295-302; Walter Gibson, "Pieter Bruegel the Elder: Two Studies" (paper presented at the Franklin D. Murphy Lectures XI, University of Kansas, Lawrence, 1991): 21-39; and Sullivan, Bruegel's Peasants, 110-15.

${ }^{44}$ Guicciardini, Description, 37-38.

${ }^{45}$ On rijstpap, a kind of rice pudding served on festive occasions, see Gibson, Pieter Bruegel and the Art of Laughter, 88. Recent literature on the Peasant Weddingincludes: Raupp, Bauernsatiren, 278-81, 283-87, 290-92; Carroll, "Peasant Festivity and Political Identity in the Sixteenth Century,"295-302; Sullivan, Bruegel's Peasants; Kavaler, Pieter Bruegel, 20-21, 59-61, 149-83,; Gibson, "Pieter Bruegel the Elder: Two Studies," 21-39; and Gibson, Pieter Bruegel and the Art of Laughter, 17-22, 50-54, 66-69, 102-3.

${ }^{46}$ Margaret D. Carroll first noted this resemblance in "Peasant Festivity and Political Identity in the Sixteenth Century," 289-314.

${ }^{47}$ The 'Adages' of Erasmus, 211.

${ }^{48}$ Ortelius, Aurei Saeculi Imago, B3.

${ }^{49}$ Aurelius, Die cronycke van Hollandt, chapter 18 (first division).

50 "Ilz ont puis apres ce vice de trop boire... Mais ils sont en quelque endroit excusables, car estant l'air du pais le plus du temps humide \& melancolique.": Guicciardini, Description, 37-38.

${ }^{51}$ On the ethnographic detail of Bruegel's peasant weddings, see the foundational work of Svetlana Alpers, "Bruegel's Festive Peasants," Simiolus 6, no. 3/4 (1972/73): 163-76.

${ }^{52}$ Orteliuis, Aurei Saeculi Imago, "Connubia"; and Aurelius, Die cronycke van Hollandt, chapter 18 (first division).

${ }^{53}$ In his short pamphlet on the Golden Age, for example, Ortelius cited a bevy of antique authors in each section of his work, including Julius Caesar, Seneca, Tacitus, Ptolemy, and Herodotus.

${ }^{54}$ The question of whether Bruegel himself visited peasant festivities originates in Karel van Mander's claim that the artist attended peasant weddings dressed in the guise of a peasant. See van Mander, The Lives of the Illustrious Netherlandish and German Painters from the First edition of the Schilder-boek (1603-1604), ed. Hessel Miedema, trans. Michael Hoyle, et al., 6 vols. (Doornspijk: Davaco, 1994 [originally published in 1624]), vol. 4, fol. 233r. Most recently the practice by Bruegel's contemporaries of visiting a peasant kermisor other festivities has been addressed by Gibson, Pieter Bruegel and the Art of Laughter, who persuasively cites a range of textual 
and pictorial evidence that such visits did take place.

55 This proverb was paraphrased by Ovid: "Ista vetus pietas, aevo moritura futuro, / Rustica saturno regna tenente fuit." Epistulae IV, 131-32. On the particular history of this proverb in the Low Countries of the Middle Ages, see A. P. Obrán, "Het spreekwoordelijke beeld van de 'rusticus,' de boer, in de Middeleeuwen," in Gewone mensen in de Middeleeuwen, ed. R. E. V Stuip and C. Vellekoop (Utrecht: HES, 1987), 75.

${ }^{56}$ Reinhart Koselleck, Futures Past: On the Semantics of Historical Time, trans. Keith Tribe (New York: Columbia University Press, 2002), 165.

${ }^{57}$ Anthony Kemp, The Estrangement of the Past: A Study in the Origins of Modern Historical Consciousness (Oxford: Oxford University Press, 1991), 157. On the triangular relation between European peasant, Europe's own pagan past, and the exotic peoples of the New World, see Michael T. Ryan, “'Assimilating New Worlds in the Sixteenth and Seventeenth Centuries," Comparative Studies in Society in History 23 (1981): 537.

${ }^{58}$ Robert Muchembled, Popular Culture and Elite Culture in France 1400-1750 (Baton Rouge and London: Louisiana State University Press, 1985), 48.

59 The question of whether Bruegel's peasants were to be viewed as either uniquely moralizing or comedic has dominated the history of Bruegel scholarship - from the famous 1970s scholarly debate on Bruegel's peasants between Svetlana Alpers and Hessel Miedema in the pages of Simiolus (See Alpers, "Festive Peasants," and Hessel Miedema, "Realism and Comic Mode: The Peasant," Simiolus 9 (1977): 205-19), the discussion of sixteenth-century peasant imagery has evolved in subsequent decades into a wider consideration of the ways in which the figure of the Netherlandish peasant could function in humanist culture and in the evolution of entrepreneurial, communal, and political identity. See, to name but a few: Margaret D. Carroll, "Peasant Festivity and Political Identity;" Ethan Matt Kavaler, "Pieter Bruegel's Fall of Icarus and the Noble Peasant," Jaarboek van het Koninklijk Museum voor Schone Kunsten (1986): 83-98; Kavaler, Pieter Bruegel; Sullivan, Bruegel's Peasants; Gibson, Pieter Bruegel and the Art of Laughter; andJürgen Müller, Das Paradox als Bildform: Studien zur Ikonologie Pieter Bruegel d. Ä. (Munich: Wilhelm Fink, 1999), 110. Rather than viewing comedy or satire as the dominant mode of reading Bruegel's peasant pictures, I agree with B. A. M. Ramakers' assessment of Bruegel's representations of the peasantry as straddling the divide between vernacular comedy and humanist wit. Ramakers argues that the peasant in sixteenth-century Netherlandish culture is a Janus-like figure of internal exoticism and self-reflection. SeeB. A. M. Ramakers, "Kinderen van Saturnus: Afstand en nabijheid van boeren in de beeldende kunst en het toneel van de zestiende eeuw," Nederlands Kunsthistorisch Jaarboek 53 (2002): 13-52; and B. A. M. Ramakers, "Bruegel en de rederijkers: Schilderkunst en literatuur in de zestiende eeuw," Nederlands Kunsthistorisch Jaarboek 47 (1997): 81-105.

${ }^{60}$ The question posed was "Welck handwerck oirboirlijest is van doene, en eerlijcst, nochtans seer cleyn gedacht?" and all competing chambers cited landwinnighe or landbouwinghe. See Spelen van sinne vol scoone moralisacien uutleggingen ende bedidenissen op alle loeflijcke consten... (Antwerp: Willem Silvius, 1562). Similarly, in a procession for the Feast of the Assumption in Antwerp in 1564, rederijkers dressed as peasants were part of the representation of a "vale of fruitfulness"; example cited in Walter Gibson, "Festive Peasants before Bruegel: Three Case Studies and Their Implications," Simiolus 31, no. 4 (2004/5): 305.

${ }^{61}$ The constraints of space do not permit an exhaustive bibliography on the satirical view of Bruegel's peasant scenes, but for further literature, see Miedema, "Realism and Comic Mode: The Peasant;" Raupp, Bauernsatiren, 316-21; and Sullivan, Bruegel's Peasants.. On the figure of the 
peasant in Netherlandish literature of the sixteenth century, see the foundational work by P. J. Meertens and Jan H. de Groot, De Lof van den Boer: De boer in de noord-en zuidnederlandsche letterkunde van de middleeuwen tot 1880(Amsterdam: C. V. Allert de Lange, 1942). For a recent summary of literature, see Herman Pleij, "Restyling 'Wisdom, Remodeling the Nobility, Caricaturing the Peasant: Urban Literature in the Late Medieval Low Countries," Journal of Interdisciplinary History 32, no. 4 (2002): 689-704.

${ }^{62}$ There were approximately 370 such villas within 25 kilometers of Antwerp in the later half of the sixteenth century, see Roland Baetens, "La 'Belezza' et la 'Magnificenza': Symboles de pouvoir de la villa rustica dans la région anversoise aux temps modernes," Nouvelle approches concernant la culture de l'habitat Antwerp (Turnhout: Brepols, 1991), 160.

${ }^{63}$ On the development and construction of the rural suburbs and the Nieuwstadof Antwerp in the period, see Hugo Soly, Urbanisme en kapitalisme te Antwerpen in de zestiende eeuw: De Stedebouwkundige en industriële ondernemingen van Gilbert van Schoonbeke (Brussels: Pro Civitate, 1977). On land reclamation of the period, see Paul Lindemans, Geschiedenis van de Landbouw in Belgie, 2 vols. (Antwerp: De Sikkel, 1952). According to van Mander, Bruegel was commissioned by the Brussels city authorities to represent the excavation of the canal linking Antwerp and Brussels, but he died before completing (or possibly even starting) the project. See van Mander, The Lives of the Illustrious Netherlandish and German Painters, fol.233v.

${ }^{64}$ Joseph Koerner has described Bruegel's ethnographic attention to the re-creation of peasant objects in paint and the meticulous description of material culture as encouraging exactly this kind of response and operating like a mask, concealing Bruegel's sophisticated pictorial manner. Joseph Leo Koerner, “Unmasking the World: Bruegel's Ethnography," Common Knowledge 10, no. 2 (2004): 229.

${ }^{65}$ For a summary of the printed predecessors to Bruegel's peasant images, see Silver, Peasant Scenes and Landscapes, chapter 6; for a discussion of domestic objects as a precursor to painted peasant scenes, see Claudia Goldstein, "Keeping Up Appearances: The Social Significance of Domestic Decoration in Antwerp, 1508-1600 ," (PhD diss., Columbia University, 2003); and for the importance of the now almost entirely lost medium of watercolor painting on cloth, see Odilia Bonebakker, "Bruegel's Transgressions: Watercolor and Oil in Sixteenth-Century Antwerp" (paper presented at the Historians of Netherlandish Art conference, Crossing Boundaries, Amsterdam, Netherlands, May 28, 2010).

${ }^{66}$ See Odilia Bonebakker, "Bruegel's Transgressions," as well as her upcoming PhD dissertation on this topic for Harvard University.

${ }^{67}$ On the importance of arboreal and satyr imagery in the German Renaissance, see Silver, "Forest Primeval" and Christopher Wood, Albrecht Altdorfer and the Origins of Landscape (Chicago: University of Chicago Press, 1993). On the similtude between John White's watercolours of Amerindians and ancient Britons, see Sam Smiles, "John White and British Antiquity: Savage Origins in the Context of Tudor Historiography," in European Visions, American Voices, ed. Kim Sloane (London: British Museum Research Publication 2009), 106-12.

${ }^{68}$ Krista De Jonge's unpublished paper, "Early Modern Architecture in the Southern and Northern Low Countries, New Challenges?" (paper presented at the Historians of Netherlandish Art conference, Crossing Boundaries, Amsterdam, Netherlands, May 27, 2010).

${ }^{69}$ There is considerable scholarly interest in the original publication of the Small Landscape series, both in the authorship of the original designs and in the claim to lifelikeness (ad vivum) made on the title page of the second series. On the drawings, see Egbert Haverkamp-Begemann "Joos van 
Liere," in Otto Georg von Simson and Matthias Winner, eds., Pieter Bruegel und seine Welt (Berlin: Kunsthistorischen Institut and Kupferstichkabinett, 1975), 17-28; Reinhard Liess "Die kleinen Landschaften Pieter Bruegels d. Ä. im Lichte seines Gesamtwerks," Kunsthistorisches Jahrbuch Graz 15 (1979): 1-116; and 17 (1981): 35-150. On the Cock prints, see Jacqueline Burgers, ed.In de Vier Winden: De prentuigeverij van Hieronymus Cock 1507/10-1570 (Rotterdam: Museum Boymans can Beuningen, 1988): cat. nos. 31-32; Walter Gibson, Pleasant Places: The Rustic Landscape from Bruegel to Ruisdael (Berkeley, Los Angeles, and London: University of California Press, 2000), 15-27; Stefaan Hautekeete, "Van Stad en Land: Het beeld van Brabant in de vroege topografische tekenkunst," in Met passer en penseel: Brussel en het oude hertogdom Brabant in beeld (Brussels: Musées Royaux des Beaux-Arts de Belgique, 2000), 46-57; and Alexandra Onuf, "Local Terrains: The Small Landscape Prints and the Depiction of the Countryside in Early Modern Antwerp" (PhD diss., Columbia University: 2005), as well as Onuf's article in this issue of the Journal of Historians of Netherlandish Art.

\section{Bibliography}

Alpers, Svetlana. "Bruegel's Festive Peasants," Simiolus 6, no. 3/4 (1972/73): 163-

76. doi:10.2307/3780341

Andriessoon, Symon. Duytsche Adagia ofte spreecwoorden. Edited by Mark Meadows and Anneke C. G. Fleurkens. Hilversum: Verloren, 2003 (Originally published in 1550).

Aurelius, Cornelis. Die cronycke van Hollandt, Zeelandt en Drieslant. Leiden: Jan Seversz., 1517.

Baetens, Roland. "La 'Belezza' et la 'Magnificenza': Symboles de pouvoir de la villa rustica dans la région anversoise aux temps modernes." In Nouvelle approches concernant la culture de l'habitat Antwerp, 159-79. Turnhout: Brepols, 1991.

Becanus, Johannes Gropius. Origines Antwerpianae. Antwerp: Plantin, 1569.

Bejczy, István. "Drie humanisten en een mythe de betekenis van Erasmus, Aurelius en Geldenhouwer voor de Bataafse kwestie." Tijdschrift voor Geschiedenis 109, no. 4 (1996): 467-84.

-——. "Erasmus Becomes a Netherlander." Sixteenth-Century Journal 28, no. 2 (1997): 38799. doi: $10.2307 / 2543449$

Bonebakker, Odilia. "Bruegel's Transgressions: Watercolor and Oil in Sixteenth-Century Antwerp." Paper presented at the Historians of Netherlandish Art conference, Crossing Boundaries, Amsterdam, Netherlands, May 28, 2010.

Boomgaard, J. E. A., et.al., ed. De uitwateringssluizen van Katwijk 1404-1984, vol. 13. Leiden: Hollandse Studiën, 1984.

Bouwsma, William J. The Waning of the Renaissance, 1550-1640.New Haven and London: Yale 
University Press, 2000.

van den Branden, L. Het Streven naar verheerlijking, zuivering en opbouw van het Nederlands in de 16de eeuw. Ghent: Koninklijke Vlaamse Academie voor Taal- en Letterkunde, 1956.

Buchanan, Iain. “The Collection of Niclaes Jongelinck: I. 'Bacchus and the Planets.” Burlington Magazine 132, no. 1043 (1990): 102-13.

."The Collection of Niclaes Jongelinck: II. The 'Months' by Pieter Bruegel the Elder." Burlington Magazine 132, no.1049 (1990): 541-50.

Burgers, Jacqueline, ed.In de Vier Winden: De prentuigeverij van Hieronymus Cock 1507/101570. Rotterdam: Museum Boymans van Beuningen, 1988.

Büttner, Nils. Die Erfindung der Landschaft: Kosmographie und Landschaftskunst im Zeitalter Bruegels. Göttingen: Vandenboeck and Ruprecht, 2000.

Carroll, Margaret D. "Peasant Festivity and Political Identity in the Sixteenth Century." Art History 10, no. 3 (1987): 289-314.

Claes, F. Lijst van Nederlandse woordenlijsten en woordenboeken gedruckt tot 1600. Nieuwkoop: B. de Graaf, 1974.

De Jonge, Krista. "Early Modern Architecture in the Southern and Northern Low Countries, New Challenges?" Paper presented at the Historians of Netherlandish Art conference, Crossing Boundaries, Amsterdam, Netherlands, May 27, 2010.

De La Fontaine, Herman. "The History of Guicciardini’s Description of the Low Countries." Quaerendo 12, no.1 (1982): 22-51. doi:10.1163/157006982X00039

Delen, A .J. J. Histoire de la gravuredans les anciens Pays-Bas et dans les provinces belges. Paris: Les Ėditions d'Art et d'Histoire, 1935.

Denucé, J. Oud-Nederlandse Kaartmakers in betrekking met Plantijn. Amsterdam: Meridian, 1964.

Divaeus, Petrus. De galliae beligicae antiquitatibus. Antwerp: Plantin, 1584.

Etter, Else-Lily.Tacitus in der Geistgeschichte des 16. und 17. Jahrhunderts. Basel and Stuttgart: Helbing \& Lichtenhahn, 1966.

Geyl, Pieter. The Revolt of the Netherlands 1555-1609. London: Ernest Benn, 1966.

van Ghistele, Cornelis. Deerste sesse boecken van Aeneas. Antwerp, 1556.

Gibson, Walter. Figures of Speech: Picturing Proverbs in Renaissance Netherlands. Berkeley, Los 
Angeles, and London: University of California Press, 2010.

.Pieter Bruegel and the Art of Laughter. Berkeley, Los Angeles, and London: University of California Press, 2006.

- _ - "Festive Peasants before Bruegel: Three Case Studies and Their Implications." Simiolus 31, no. 4 (2004/5): 292-309.

. "Pieter Bruegel the Elder: Two Studies." Paper presented at the Franklin D. Murphy Lectures XI, University of Kansas, Lawrence, 1991.

.'Some Notes on Pieter Bruegel the Elder's Peasant Wedding Feast." Art Quarterly 28, no. 3 (1965): 194-208.

-_- Pleasant Places: The Rustic Landscape from Bruegel to Ruisdael. Berkeley, Los Angeles, and London: University of California, 2000.

Goldstein, Claudia. "Keeping Up Appearances: The Social Significance of Domestic Decoration in Antwerp, 1508-1600." PhD diss., Columbia University, 2003.

Guicciardini, Lodovico. Description de tout le Païs bas. Antwerp: William Silvius, 1567 (originally published in Italian as Descrittionedi tutti i Paesi Bassi).

Haskell, Francis. History and Its Images: Art and the Interpretation of the Past. New Haven and London: Yale University Press, 1993.

Hautekeete, Stefaan. "Van Stad en Land: Het beeld van Brabant in de vroege topografische tekenkunst." In Met passer en penseel: Brussel en het oude hertogdom Brabant in beeld, 46-57. Brussels: Musées Royaux des Beaux-Arts de Belgique, 2000.

Haverkamp-Begemann, Egbert. “Joos van Liere.” In Pieter Bruegel und seine Welt, edited by Otto Georg von Simson and Matthias Winner,17-28. Berlin: Kunsthistorischen Institut and Kupferstichkabinett, 1975.

Hemelaar, Femke. "Bold and Fervid: The Ideology of Rhetorical Translation in Sixteenth-century Antwerp." Paper given at Understanding Art in Antwerp,1540-80: Classicizing the Popular, Popularizing the Classic, Groningen, Netherlands, January 23-24, 2008. Groningen: Groningen Research School for the Study of Humanities, 2008.

Hessels, J. H. Abrahami Ortelii epistulae. Cambridge: Typis Academiae, 1887.

Hessing, Wilfried. "Foreign Oppressor versus Civiliser: The Batavian Myth as a Source for Contrasting Associations with Rome in Dutch Historiography and Archaeology." In Images of Rome: Perceptions of Ancient Rome in Europe and the United States in the Modern Age = Journal of Roman Archaeology, supplement (2001), edited by Richard Hingley, 126-44. 
Hogden, Margaret T. Early Anthropology in the Sixteenth and Seventeenth Centuries. Philadelphia: University of Pennsylvania Press, 1964.

Jansen, Jeroen. "Purity and the Language of the Court in the Late Sixteenth and Seventeenth-Century Netherlands." In The Vulgar Tongue, edited by Fiona Somerset and Nicholas Watson, 166-76. Philadelphia: Penn State University Press, 2003.

Karrow, R. W. "Abraham Ortelius: Een introductie." In Abraham Ortelius: Cartograaf en humanist, edited by Pierre Cockshaw, et al., 25-30. Turnhout, Antwerp, and Brussels: Brepols, Museum Plantin-Moretus, and Koninklijk Bibliotheek im België, 1998.

Kavaler, Ethan Matt. "Pieter Bruegel's Fall of Icarus and the Noble Peasant." Jaarboek van het Koninklijk Museum voor Schone Kunsten (1986): 83-98.

Press, 1999.

Pieter Bruegel: Parables of Order and Enterprise. Cambridge: Cambridge University

Kelley, Donald R. "Altera Natur: The Idea of Custom in Historical Perspective." In New Perspectives on Renaissance Thought: Essays in the History of Science, Education and Philosophy, edited by John Henry and Sarah Hutton, 83-100.London: Gerald Duckworth, 1990.

Kemp, Anthony. The Estrangement of the Past: A Study in the Origins of Modern Historical Consciousness. Oxford: Oxford University Press, 1991.

Koerner, Joseph Leo. "Unmasking the World: Bruegel's Ethnography." Common Knowledge 10, no. 2 (2004): 220-51. doi:10.1215/0961754X-10-2-220

Koselleck, Reinhart. Futures Past: On the Semantics of Historical Time. Translated by Keith Tribe. New York: Columbia University Press, 2002.

Lambrecht, Joas. Nederlandsche spellynghe. Ghent: Joas Lambrecht, 1550.

Langereis, Sandra. "Van bote boeren tot beschaafde burgers: Oudheidkundige beelden van de Bataven 1500-1800." In De Bataven verhalen van den verdwenen volk, edited by Louis Swinkels, 72-108. Amsterdam and Nijmegen: De Bataafsche leeuw and Museum Het Valkhof, 2004.

Liess, Reinhard. "Die kleinen Landschaften Pieter Bruegels d. Ä. im Lichte seines Gesamtwerks." Kunsthistorisches Jahrbuch Graz 15 (1979): 1-116; and 17 (1981): 35-150.

Lindemans, Paul. Geschiedenis van de Landbouw in België. 2 vols. Antwerp: De Sikkel, 1952.

Lipsius, Justus. Epistolarum selectarum centuria prima ad Belgas. Antwerp: Moretus, 1602.

van Mander, Karel. The Lives of the Illustrious Netherlandish and German Painters from the First 
Edition of the Schilder-boek (1603-1604). Translated by Michael Hoyle, Hessel Miedema, Jacqueline Penniall-Boer, and Charles Ford. Edited by Hessel Miedema. 6 vols. Doornspijk: Davaco, 1994 (Originally published in 1624).

Margolin, Jean-Claude "Science et nationalisme linguistique ou la bataille pour l'étymologie au XVI siècle." In TheFairest Flower: The Emergence of Linguistic National Consciousness in Renaissance Europe, 139-65. Proceedings of the International Conference of the Center for Medieval and Renaissance Studies, University of California at Los Angeles, December 12-13, 1983. Florence: Presso l’Academia della Crusca, 1985.

Martial. Epigrams. Translated by James Michie. New York: Modern Library, 2002.

McTaggert, Timothy, ed. Musyck boexken:Dutch Songs for Four Voices. Madison, Wis.: A-R Editions, 1997.

Meertens, P. J., and Jan H de Groot. De Lof van den Boer: De boer in de noord-en zuidnederlandsche letterkunde van de middleeuwen tot 1880. Amsterdam: C. V. Allert de Lange, 1942.

Meganck, Tine L."Abraham Ortelius, Hubertus Goltzius en Guido Laurinus en de studie van de Arx Britannica." Koninklijke Nederlandse Oudheidkundige Bond 98, no. 5/6 (1999): 226-36.

. "Erudite Eyes: Artists and Antiquarians in the Circle of Abraham Ortelius (15271598).” PhD diss., Princeton University, 2003.

Miedema, Hessel. “Realism and Comic Mode: The Peasant.” Simiolus 9 (1977): 20519. doi: $10.2307 / 3780555$

Mielke, Hans. Pieter Bruegel: Die Zeichnungen. Turnhout: Brepols, 1996.

van Miert, Dirk. “La Batavia de Adriano Junio (1511-1575).” In Humanismo y pervivencia del mundo clásico: Homenaje al profesor Antonio Fontán, vol. 3, edited by José Maestere Maestere, et al., 1513-20. Madrid: Instituto de Estudios Humanísticos-CSIC, 2002.

Monballieu, A. “De 'Kermis van Hoboken' van P. Bruegel, J. Grimmer en G. Mostaert.” Jaarboek van het Koninklijk Museum voor Schone Kunsten (1974): 139-69.

Mout, M. E. H. N. “'Het Bataafse Oor’ De lotgevallen van Erasmus' adagium 'Aurij Batava' in de Nederlandse geschiedschrijving." Koninklijk Nederlandse Akademie van Wetenschappen 56, no. 2 (1993): 77-102.

Muchembled, Robert. Popular Culture and Elite Culture in France 1400-1750. Baton Rouge and London: Louisiana State University Press, 1985.

Müller, Jürgen. Das Paradox als Bildform: Studien zur Ikonologie Pieter Bruegel d. Ä. Munich: Wilhelm Fink, 1999. 
Müller-Hofstede, Justus. “Zur Interpretation von Bruegels Landschaft. Äesthetischer Landschaftsbegriff und Stoische Weltbetrachtung." In Pieter Bruegelund seine Welt, edited by Otto Georg von Simson and Matthias Winner, 73-142. Berlin: Mann, 1979.

Münster, Sebastian. Cosmographiae universalis. Basel: Henri Petri, 1550.

Obrán, A. P. "Het spreekwoordelijke beeld van de 'rusticus', de boer, in de Middeleeuwen." In Gewone mensen in de Middeleeuwen, edited by R. E. VStuip and C. Vellekoop, 22-50. Utrecht:HES, 1987.

Onuf, Alexandra. "Local Terrains: The Small Landscape Prints and the Depiction of the Countryside in Early Modern Antwerp." PhD. diss., Columbia University, 2005.

. "Envisioning Netherlandish Unity: Claes Visscher's 1612 Copies of the Small Landscape Prints." Journal of Historians of Netherlandish Art 3, no. 1 (2011). Online at www.jhna.org.

Orenstein, Nadine M., ed., Pieter Bruegel the Elder: Drawings and Prints. New Haven, New York, and London: Metropolitan Museum of Art and Yale University Press, 2001.

Ortelius, Abraham. Aurei Saeculi Imago sive germanorum veerum vita, mores, ritus \& religio. Antwerp: P. Galle, 1596.

Aurei Saeculi Imago of Spiegel van de Gouden Tijd, ediited and translated by Joost Depuydt and Jeanine De Landtsheer. Wildert: De Carbolineum, 1999.

Phillips, Margaret Mann, ed. and trans. The 'Adages' of Erasmus: A Study with Translations. Cambridge: Cambridge University Press, 1964

Pleij, Herman. "Restyling 'Wisdom,' Remodeling the Nobility, Caricaturing the Peasant: Urban Literature in the Late Medieval Low Countries." Journal of Interdisciplinary History 32, no. 4 (2002): 689-704. doi:10.1162/002219502317345565

Ramakers, B. A. M. "Kinderen van Saturnus: Afstand en nabijheid van boeren in de beeldende kunst en het toneel van de zestiende eeuw," Nederlands Kunsthistorisch Jaarboek 53 (2002): 13-52.

."Bruegel en de rederijkers: Schilderkunst en literatuur in de zestiende eeuw." Nederlands Kunsthistorisch Jaarboek 47 (1997): 81-105.

Raupp, Hans-Joachim.Bauernsatiren: Entstehung und Entwicklung des bäuerlichen Genres in der deutschen und niederländischen Kunst ca. 1470-1570.Niederzier: Lukassen, 1986.

Riemsdijk, J. C. M. "De twee eerste musyckboekskens van Tielman Susato: Bijdrage tot het Nederlandsch Volkslied in de 16de eeuw." Tijdschrift der Vereeniging voor Noord-Nederlands Muziekgeschiedenis 3, no. 2 (1888): 61-110. doi:10.2307/947830 
Riggs, Timothy. "Hieronymus Cock. Printmaker and Publisher." PhD. diss., Yale University, 1971.

Ryan, Michael T. "Assimilating New Worlds in the Sixteenth and Seventeenth Centuries." Comparative Studies in Society in History 23 (1981): 519-38. doi:10.1017/S0010417500013542

Scaliger, Julius Caesar. M. Verrrii Flacci quae extant. Et Sex. Pompeii Festi... Paris: M. Patissonum, 1576.

Schnapp, Alain. The Discovery of Time: The Origins of Archaeology. Translated by Ian Kinnes and Gillian Varndell. London: British Museum Press, 1996.

Schöffer, I. "The Batavian Myth during the Sixteenth and Seventeenth Centuries." In Britain and the Netherlands V, edited by J. S. Bromley and E. H. Kossmann, 78-101. The Hague: Martinus Nijhoff, 1975.

Silver, Larry. Peasant Scenes and Landscapes: The Rise of Pictorial Genre in the Antwerp Art Market. Philadelphia: University of Pennsylvania Press, 2006.

. "Forest Primeval: Albrecht Altdorfer and the German Wilderness Landscape." Simiolus13, no. 1 (1983): 4-43. doi:10.2307/3780605

Spelen van sinne vol scoone moralisacien uutleggingen ende bedidenissen op alle loeflijcke consten... Antwerp: Willem Silvius, 1562.

Smiles, Sam. "John White and British Antiquity: Savage Origins in the Context of Tudor Historiography." In European Visions, American Voices, edited by Kim Sloane, 106-12. London: British Museum Research Publications, 2009.

Soly, Hugo. Urbanisme en kapitalisme te Antwerpen in de zestiende eeuw: De Stedebouwkundige en industriële ondernemingen van Gilbert van Schoonbeke. Brussels: Pro Civitate, 1977.

Sullivan, Margaret. Bruegel's Peasants: Art and Audience in the Northern Renaissance. Cambridge: Cambridge University Press, 1994.

Tacitus. The Agricola and the Germania. Translated by H. Mattingly. London: Penguin, 1970.

Tilmans, Karen. Historiography and Humanism in Holland in the Age of Erasmus: Aurelius and the Divisiekroniek of 1517. Translated by Sam Herman. Nieuwkroop: De Graaf, 1992.

- - - "Aeneas, Bato and Civilis, the Forefathers of the Dutch: The Origins of the Batavian Tradition in the Dutch Humanistic Historiography." In Renaissance Culture in Context: Theory and Practice, edited by Jean R. Brink and William F. Gentrup, 121-35. Aldershot: Scholar Press, 1993.

t'Sestich, Anton. Orthographia Linguae Belgicae. Leuven: Joannes Masius, 1576. 
Vandenbroeck, Paul. Beeldvan de andere, vertoog over het zelf. Antwerp: Koninklijk Museum voor Schone Kunst, 1987.

van der Werve, Jan. Het Tresoor der Duytsscher Talen. Antwerp: Hans de Laet, 1553.

Wesseling, Ari. “Are the Dutch Uncivilised?': Erasmus on the Batavians and His National Identity." Erasmus of Rotterdam Society Yearbook 13 (1993): 68-102.

Wood, Christopher. Albrecht Altdorfer and the Origins of Landscape. Chicago: University of Chicago Press, 1993. 